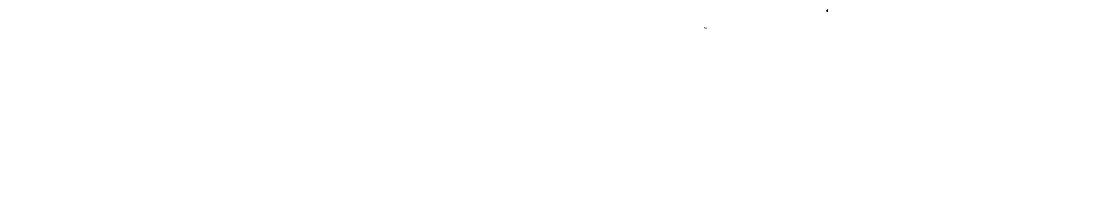

\title{
INVESTIGATION OF AUSTENITIC ALLOYS FOR ADVANCED HEAT RECOVERY AND HOT GAS CLEANUP SYSTEMS
}

\author{
R. W. Swindeman \\ Metals and Ceramics Division \\ Oak Ridge National Laboratory, Oak Ridge, Tennessee, 37830

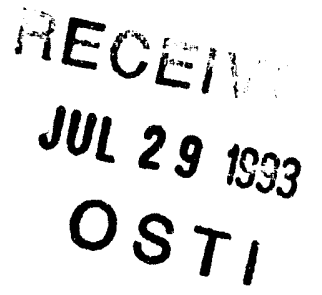

ABSTRACT

Commercial and developmental alloys were evaluated in support of advanced steam cycle and combined cycle technology. Working with industrial groups, Grade 91 steel, which is a candidate for main steam line piping and superheater tubing in advanced steam cycle plants, was re-evaluated to examine metallurgical factors that influence long-time performance to $600^{\circ} \mathrm{C}$. Deformation models and aging effect models were developed. Testing of corrosion-resistant filler metals for tubing was extended to times approaching $30,000 \mathrm{~h}$. Good strengths were observed. Modified type 310 stainless steels were examined to $927^{\circ} \mathrm{C}$. It was found that these steels had up to twice the strength of standard type $310 \mathrm{H}$ stainless steel. The behavior of aluminum-bearing alloys and high chromium alloys was examined for potential applications $10870^{\circ} \mathrm{C}$. Thermal cycling of clad tubing was undertaken, and good performance was found.

\section{INTRODUCTION}

Research on austenitic alloys for advanced steam cycle applications was begun six years ago in support of a research effort by the Electric Power Research Institute (EPRI) to improve performance of pulverized coal power plants (1). The initial thrust at ORNL was to evaluate austenitic alloys that could be used for superheater tubing in the EPRI Phase 2 conceptual plant. The target was an alloy for the production of steam at $650^{\circ} \mathrm{C}$ and $35 \mathrm{MPa}$. The EPRI Phase 2 effort received very little support by the U.S. utility industry. Interest continued in the EPRI Phase 1 conceptual plant, however, and several advanced alloys that EPRI helped to develop for this application in Japan are approaching Code status in the U.S. These materials included Sumitomo HR3C stainless steel, Nippon Steel NF 709, and Nippon Steel NF 616. When Code approved, these alloys will be available for use in plant life extension and re-powering. State-of-the-art combined cycle concepts and second generation combined cycle concepts received attention from the DOE energy technology centers as well as from EPRI, utilities, and industry in the U.S. $\tilde{F}$ Europe, and Japan. Recognizing that issues remain regarding the use of new materials for re- 
powering and combined cycle concepts, the work described below represents the efforts undertaken in the last year to collaborate with the fossil power industry in various areas of structural materials technology. Topics that are covered include plant life extension, increase of steam temperatures to $600^{\circ} \mathrm{C}$, hot-gas cleanup for pressured fluidized bed combustors, and structural alloys for second generation combined cycle applications.

\section{PLANT LIFE EXTENSION}

One effort on plant life extension involved the continuation of stress-rupture tests on type $316 \mathrm{~N}$ stainless steel and CRE 16-8-2 weld metal for joining high-strength austenitic stainless steels used in main steam line piping. This work was begun as a collaborative effort with South Carolina Gas and Electric Company and Tordonato Energy Consultants, Inc. and testing has continued to beyond $20,000 \mathrm{~h}$ with excellent strength and ductility being observed in $316 \mathrm{~N}$ stainless steel that had been in service at $540^{\circ} \mathrm{C}$ for approximately $95,000 \mathrm{~h}$ (2). See Fig. 1.

Another effort on plant life extension involved the use of Gr-91 steel in superheaters and headers. Superheater tubing in the Tennessee Valley Authority (TVA) Kingston Steam Plant Unit 5 was inspected after 10 years of operation. The tubing was found to be in excellent condition. Stress rupture data on aged Gr-91 steel were evaluated, and a simple rule for prediction of creep response after aging was developed (3). Working with Tordonato Energy Consultants, Inc., a model was developed for the prediction of tertiary creep response in Gr-91 steel (4). See Fig. 2. Additional testing of Gr-91 was undertaken to assist in the evaluation of a tube failure due to a temperature excursion in a power boiler.

\section{ADVANCED STEAM CYCLE}

Research was undertaken to support the advanced steam cycle goal of producing steam at $600^{\circ} \mathrm{C}$. The influence of thermal mechanical treatment on the strength and ductility of the modified alloy $800 \mathrm{H}$ was examined for times approaching $20,000 \mathrm{~h}$ and for temperatures to $730^{\circ} \mathrm{C}$. The modified $800 \mathrm{H}$ alloy was found to be tolerant of cold work to levels of $15 \%$ without loss of strength due to recrystallization. See Fig. 3. Weld metals such as CRE 16-8-2 stainless steel and alloy 556 continued to exhibit good properties after testing times exceeding $20,000 \mathrm{~h}$.

A significant effort continued on the performance of $\mathrm{Gr}-91$ in advanced steam cycle applications. Stress rupture data from around the world have been collected and re-evaluated for service to 
$600^{\circ} \mathrm{C}$ and higher. Additional testing was performed to examine techniques for extrapolation of data. Techniques included time-temperature parametric procedures. isostress testing, and Monkman Grant analyses (5). This collaborative effort involied Geman and Japanese researchers, and the combined stress-rupture data are shown in Fig. 4. The log stress is plotted against the Dorn parameter for more than 800 tests. Overall, the trend of the data indicated that the original stress values proposed for temperatures in the range of $57510650^{\circ} \mathrm{C}$ were adequate. The European steels tended to be somewhat weaker than the U.S. and Japanese steels, and some adjustment of design stresses may be forthcoming. To accommodate the loss in strength due to long time aging a model was developed that correlated life with aging time (5). This model is being tested with a new sec of tests on aged materials. An effor has been started to collaborate with a major U.S. utility, a boiler manufacturer, and a university to examine the performance of Gr91 thick-section weldments in a header vessel for service to $610^{\circ} \mathrm{C}$. The material is the first commercial heat of Gr-91 melted in the U.S. in more than ten years.

\section{HOT-GAS CLEANUP}

Materials and design methods for construction of structural components in hot-gas cleanup vessels for pressurized fluidized bed combustors (PFBC) are being evaluated. Coupons of several structural alloys (alloy 556, alloy 333, RA85H stainless steel, and $310 \mathrm{HCbN}$ stainless steel) were supplied to Westinghouse Electric Corporation for exposure in the Tidd Plant gas filter vessel (6). Creep and fatigue of materials such as RA-333 and alloy 556 is continuing at a relatively low level of effort. Alloy 556 was approved recently for construction under the rules of ASME Sect. VIII for temperature to $870^{\circ} \mathrm{C}$. Because of the low yield strengths of commercially available high temperature structural alloys, they are susceptible to low-cycle fatigue failures under restrained thermal cycling conditions. A nickel-chromium -aluminide intermetallic alloy was selected as an alternative material for tube sheet construction because of its very high yield strength at $870^{\circ} \mathrm{C}$. Cyclic testing of IC $396 \mathrm{M}$ was continued to produce a data base sufficient for elastic-plastic-creep analysis in structural applications in a collaborative effort with Mallett Software Technology, Inc. Under conditions of 50\% restraint, virtually no inelastic strains occurred after the first transient in IC $396 \mathrm{M}$ cycled between 150 and $835^{\circ} \mathrm{C}$. After shakedown, themal transients produce only elastic strains. A typical response curve is shown in Fig. 5.

\section{SECOND GENERATION COMBINED CYCLE}

Materials and design methods for second generation combined cycle plants were examined. In a collaborative effort with Stress Engineering Services, Inc., criteria for design above $815^{\circ} \mathrm{C}$ were 
studied (6). The initial work was undertaken on alloy 80() $\mathrm{H}$ to determine the degree of conservatism embedded in the existing criteria for design in the various Sections of the ASME Boiler and Pressure Vessel Code. Studies were extended to other Code alloys and candidate structural alloys. Of particular interest has been the shape of the creep curve at very high temperatures and the response to cyclic loading in the presence of aggressive environments. Alloy 333, 253MA stainless steel, and RA85H stainless steel were evaluated in collaboration with Rolled Alloys, Inc.

After consulting with several contractors involved in the design of second generation combined cycle system components, it became clear that many materials issues needed resolution. For PFBC gas streams, material selection for piping liners, expansion bellows, and filter supports were areas of importance. Type 310 stainless steel was a primary candidate on the basis of cost, but stronger alloys were sometimes needed. Carbonizers and gasifier gas streams presented greater problems because of the greater potential for sulfidation.

The potential of modified type 310 stainless steel for fossil energy applications at temperatures above $815^{\circ} \mathrm{C}(8)$ was assessed, and it was concluded that a $25 \mathrm{Cr}-20 \mathrm{Ni}$ steel having a strength comparable to alloy $800 \mathrm{H}$ would be of interest. Two commercial heats of $310 \mathrm{HCbN}$ stainless sieel tubing were procured, annealed at $1200^{\circ} \mathrm{C}$, and subjected to creep-rupture testing in the temperature range of 760 to $982^{\circ} \mathrm{C}$. To date, both heats have exhibited good strength and ductility and were stronger than alloy $8(00 \mathrm{H}$. One experimental heat of a Ta-modified 310 stainless steel was procured as an ingot. The ingot was hot rolled to $13-\mathrm{mm}$ plate, annealed at $12(1)^{\circ} \mathrm{C}$, and specimens were creep-rupture tested in the temperature range of 760 to $1038^{\circ} \mathrm{C}$. The alloy' was found to have excellent creep strength(Fig. 6). Exploratory testing in regard to cyclic oxidation resistance and 5 roe weldability indicated favorable trends. Thus, lower cost alloys with improved strength may become available for use in non-sulfidizing environments.

For protection against coal-ash corrosion at temperatures above $760^{\circ} \mathrm{C}$, exploratory testing of tubing clad with alloy 671 and alloy 690 was undertaken (8). Tube sections of alloy $800 \mathrm{H}$ clad with alloy 671 and modified alloy $800 \mathrm{H}$ clad with alloy 690 were subjected to cyclic oxidation testing to $900^{\circ} \mathrm{C}$ for $500 \mathrm{~h}$. Each day the tubes were cooled to near room temperature. The purpose was to examine cyclic oxidation characteristics of the base metal and the character of the clad base metal interface. Both the $671 / 800$ and the $690 / \bmod 800$ clad interfaces exhibited no detrimental changes (Figs. 7 and 8), but the modified alloy 800 showed severe oxide attack on the unclad inside diameter. A bare $310 \mathrm{HCbN}$ stainless steel tube was subjected to similar cycling and, based on inspection of the surface, exhibited good oxidation resistance. Quantitative 
measurements of oxidation rates are being planned.

For protection against sulfidizing environments, the potential of iron-aluminide cladding is being explored. For carbonizer and gasifier gas streams operating to $900^{\circ} \mathrm{C}$, the aluminide cladding on piping liners and internal vessel structural components is being considered. To examine the compatibility of the base metal and cladding, cyclic testing of aluminide clad 304 stainless steel tubing was undertaken. Testing was performed at 760 and $900^{\circ} \mathrm{C}$ for $500 \mathrm{~h}$ with a cool down to near room temperature each day. The clad base metal interface exhibited no detrimental changes, as shown in Fig. 9.

\section{SUMMARY}

Progress has been made on the evaluation of structural materials for a number of fossil energy applications, and most of the research involves collaborative efforts with industry. The selectrof... of materials and research thrusts were selected to meet the needs of industrial partners. Several issues regarding the use of Gr-91 steel in life extension and re 2 powering were addressed. Materials for construction of components in second generation combined cycle applications were examined, and emphasis was placed on gathering data needed for establishing design methods and analysis procedures.

1. S. B. Bennett, Engineering Assessmem of an Advanced Pulverized Coal Powe'r Plant, EPRI CS-2555, Electric Power Research Institute, Palo Alto, CA, August 1982.

2. R. W. Swindeman, G. M. Goodwin, and F. V. Ellis, "Filler Metals for Type 316N Stainless Steel," pp. 33 -39 in Stress Classification, Robust Methods, and Elevated Temperarure Design, PVP-Vol. 230, American Society of Mechanical Engineers, New York, NY, 1992.

3. R. W. Swindeman, "Creep Response of a $9 \mathrm{Cr}-1 \mathrm{Mo}-\mathrm{V}-\mathrm{Nb}$ Steel to Varying Stresses and Temperatures," pp. 900-13 in Proceedings of International Conference on Pressure V'essel Technology 7, Dusseldorf, Germany, 1992.

4. F. V. Ellis and R. W. Swindeman, "Modelling Tertiary Creep in 9Cr-1Mo-V Steel," paper presented at the ASME Pressure Vessels and Piping Conference, Denver, Colorado, July 25-29, 1993. 
5. R. W. Swindeman, C. R. Brinkman, and H. D. Upton, "Rupture Life Prediction for 9Cr-1MoV-Nb Steel," paper presented at the International Symposium on Improved Technology for Fossil Power Plants-New \& Retrofit Applications, Washington, D.C., 1993.

6. M. J. Mudd, "Initial Operation of the Tidd PFBC HGCU Test Facility," pp. 27-33 in Proceedings of the Ninth Annual Coal-Fueled Heat Engines, Advanced Pressurized Fluidized-Bed Combustion (PFBC), and Gas Stream Cleanup Systems Contractors Review Meeting, DOE/METC-93/6129, Morgantown Energy Technology Center, Morgantown, WV, October, 1992.

7. R. W. Swindeman and D. L. Marriott, "Criteria for Design with Structural Materials in Combined-Cycle Applications above $815^{\circ} \mathrm{C}$," paper presented at the ASME International Gas Turbine Conference, Cincinnati, Ohio, May, 1993.

8. R. W. Swindernan, The Potential of Modified Type 310 Stainiess Steel for Advanced Fossil Energy Applications, ORNL-TM-12057 (March, 1992).

9. R. W. Swindeman, Summary of Work on Coatings and Claddings for Fossil Energy Applications, ORNL-TM draft report to be published in May 1993.

\section{Acknowledgements}

This research sponsored by the U.S. Department of Energy, Office of Fossil Energy, Advanced Research and Technology Development Materials Program, under contract DE-ACO5-84OR21400 with Martin Marietta Energy Systems, Inc.

\section{DISCLAIMER}

This report was prepared as an account of work sponsored by an agency of the United States Government. Neither the United States Government nor any agency thereof, nor any of their employees, makes any warranty, express or implied, or assumes any legal liability or responsibility for the accuracy, completeness, or usefulness of any information, apparatus, product, or process disclosed, or represents that its use would not infringe privately owned rights. Reference herein to any specific commercial product, process, or service by trade name, trademark, manufacturer, or otherwise does not necessarily constitute or imply its endorsement, recommendation, or favoring by the United States Government or any agency thereof. The views and opinions of authors expressed herein do not necessarily state or reflect those of the United States Government or any agency thereof. 
Figures

Fig. 1. Creep curves for type $316 \mathrm{~N}$ stainless steel removed from the main steam line piping of a fossil power plant after $95,000 \mathrm{~h}$ at $540^{\circ} \mathrm{C}$.

Fig. 2. Comparison of long time creep curves for Gr-91 with a model developed by Ellis and Swindeman to include tertiary creep.

Fig. 3. Influence of cold work on the rupture strength of modified alloy 800 tested at temperatures in the range of 600 to $760^{\circ} \mathrm{C}$.

Fig. 4. Log stress versus the Dorn-Shepard parameter correlating life and temperature for stress rupture data on Gr-91 steel produced by U.S., Japanese, and German sources.

Fig. 5. Stress versus strain response of intemetallic alloy IC396M during thermal cycles of 150 to $835^{\circ} \mathrm{C}$ with $50 \%$ restraint.

Fig. 6. Comparison of the $1000 \mathrm{~h}$ rupture strength for several alloys over the temperature range of 650 to $1100^{\circ} \mathrm{C}$.

Fig. 7. Microstructure of the interface between alloy 671 cladding and alloy $800 \mathrm{H}$ after $500 \mathrm{~h}$ at $900^{\circ} \mathrm{C}$ with one thermal cycle to near room temperature each day.

Fig. 8. Microstructure of the interface between alloy 690 cladding and modified alloy $800 \mathrm{H}$ after $500 \mathrm{~h}$ at $900^{\circ} \mathrm{C}$ with one thermal cycle to near room temperature each day.

Fig. 9. Microstructure of the interface between iron aluminide cladding and 304 stainless steel after $500 \mathrm{~h}$ at $900^{\circ} \mathrm{C}$ with one thennal cycle to near room temperature each day 


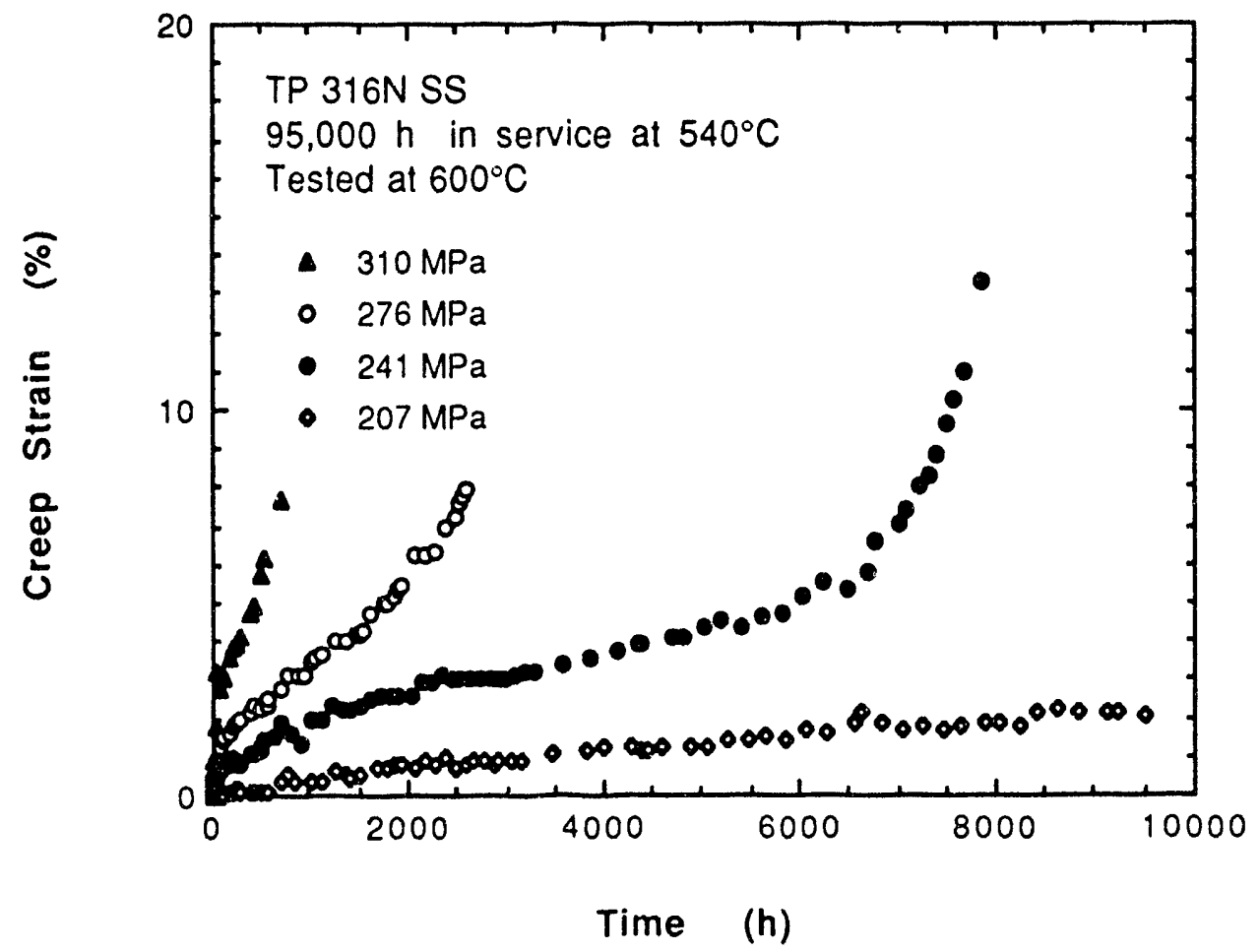

Fig. 1. Creep curves for type $316 \mathrm{~N}$ stainless steel removed from the main steam line piping of a fossil power plant after $95,000 \mathrm{~h}$ at $540^{\circ} \mathrm{C}$. 


\section{Creep Strain Versus Time For Grade 91 Heat $30383 ; 593 \mathrm{C}$ and $110 \mathrm{MPa}$}

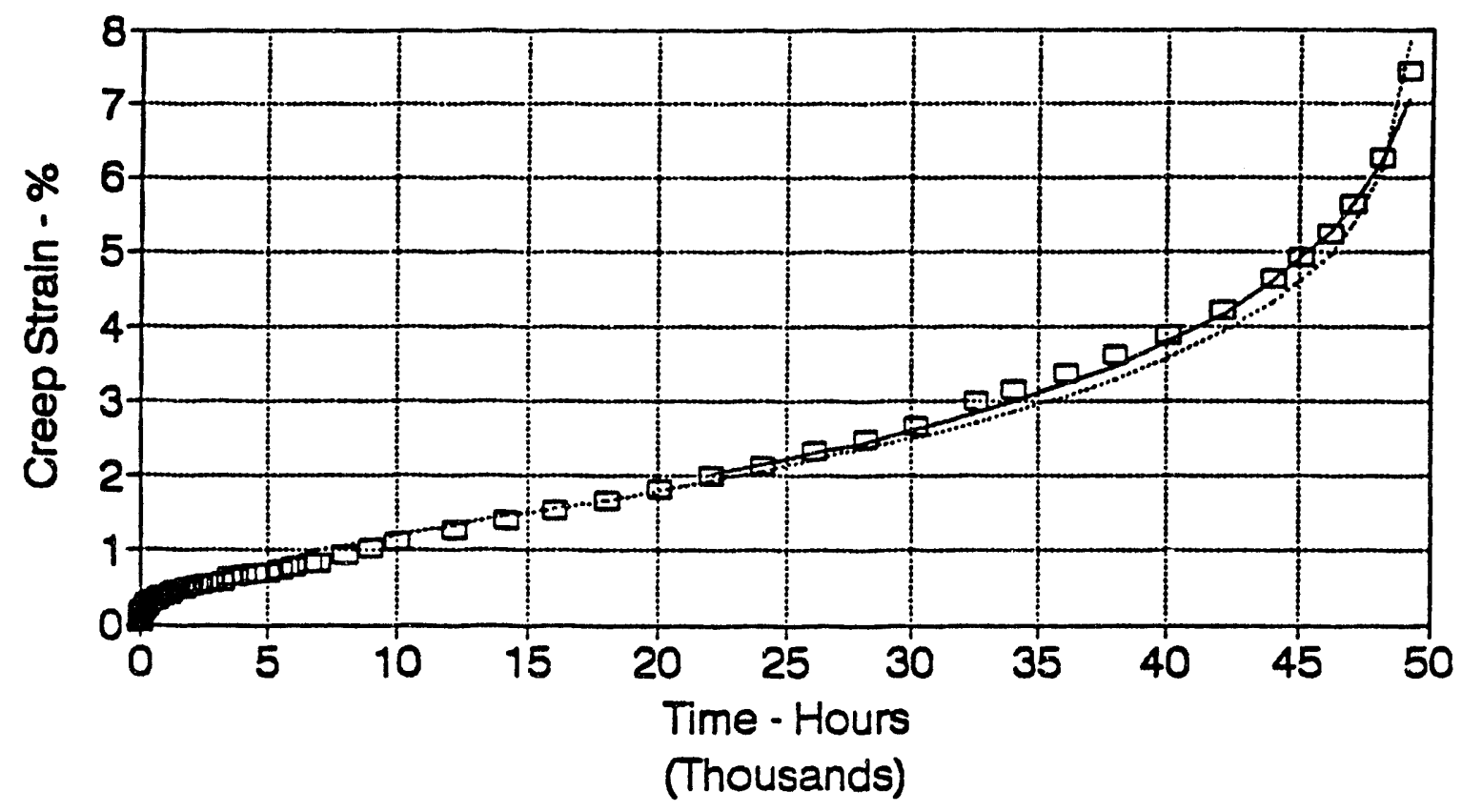

- Observed - Complete - Tertiary

Fig. 2. Comparison of long time creep curves for $\mathrm{Gr}-91$ with a model developed by Ellis and Swindeman to include tertiary creep. 


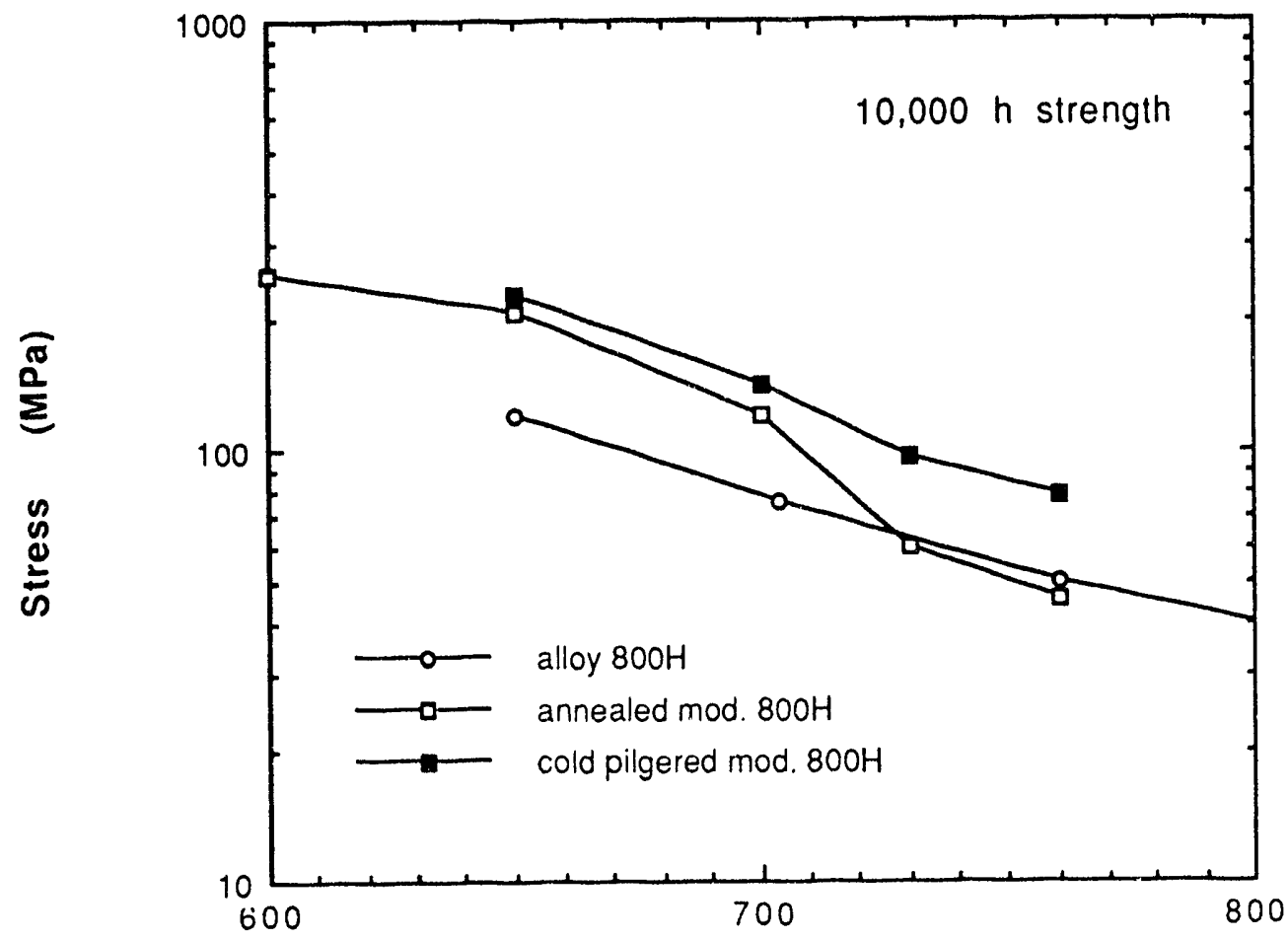

Temperature $\left({ }^{\circ} \mathrm{C}\right)$

Fig. 3. Infiuence of cold work on the rupture strength of modified alloy 800 tested at temperatures in the range of 600 to $760^{\circ} \mathrm{C}$. 


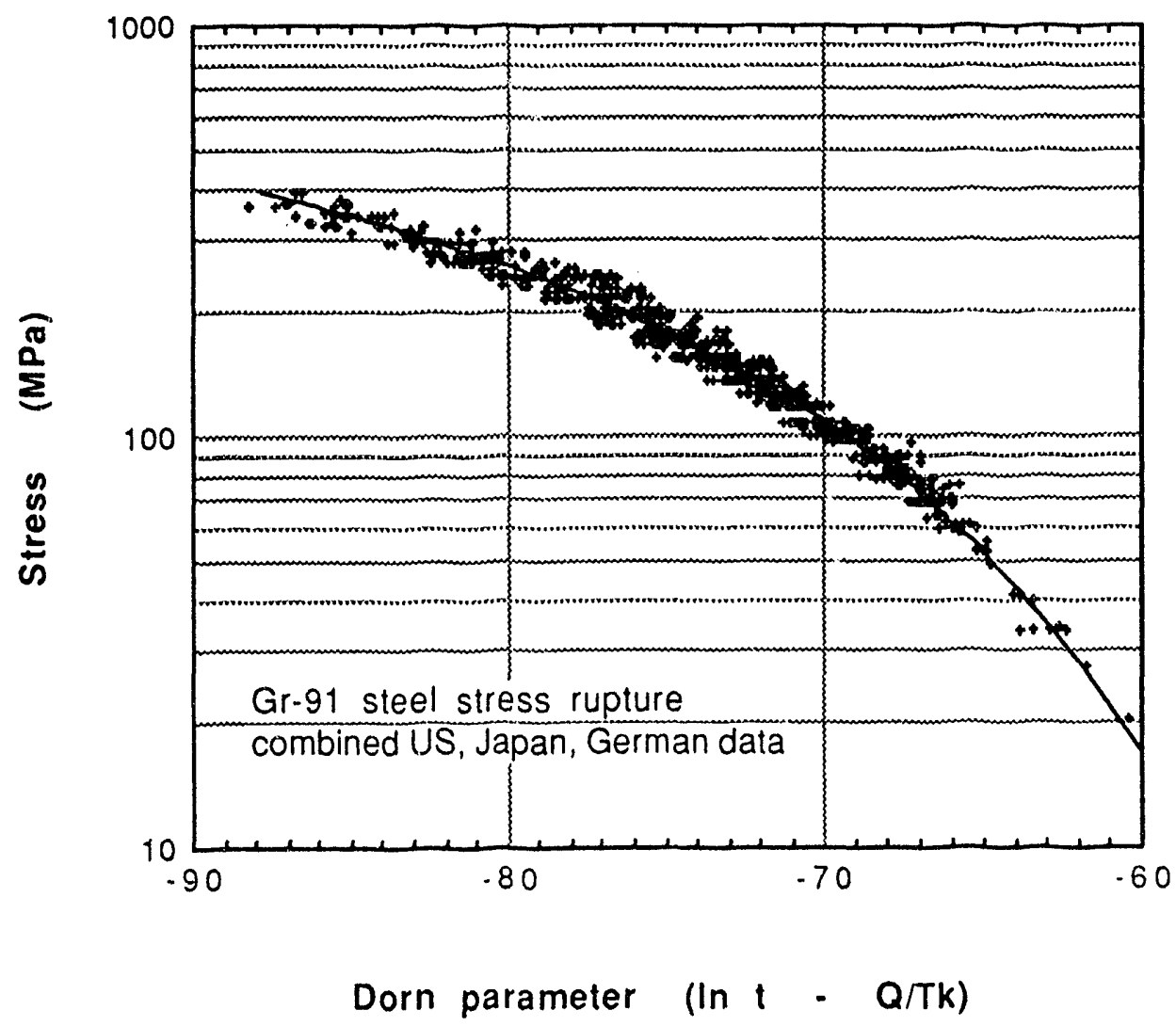

Fig. 4. Log stress versus the Dorn-Shepard parameter correlating life and temperature for stress rupture data on Gr-91 steel produced by U.S., Japanese, and German sources. 


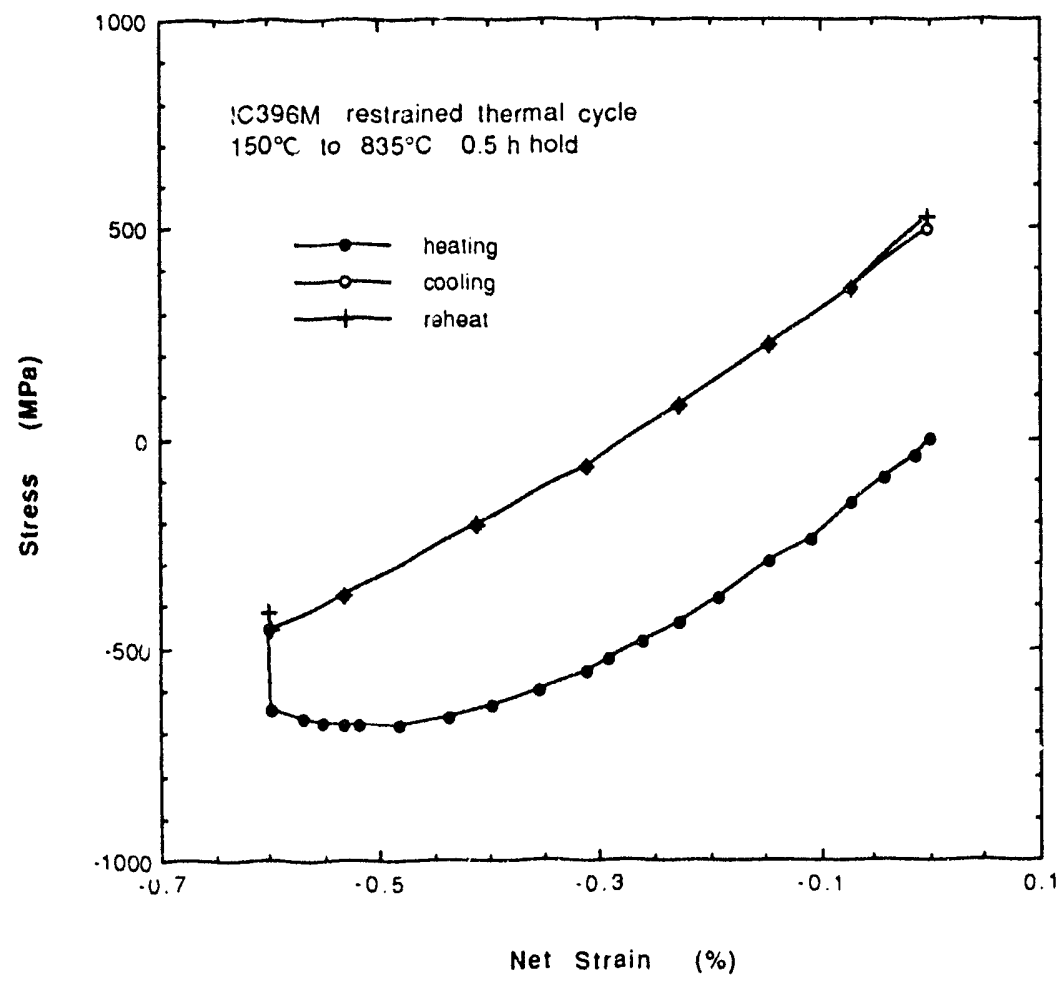

Fig. 5. Stress versus strain response of intermetallic alloy IC $396 \mathrm{M}$ during thermal cycles of 150 to $835^{\circ} \mathrm{C}$ with $50 \%$ restraint. 

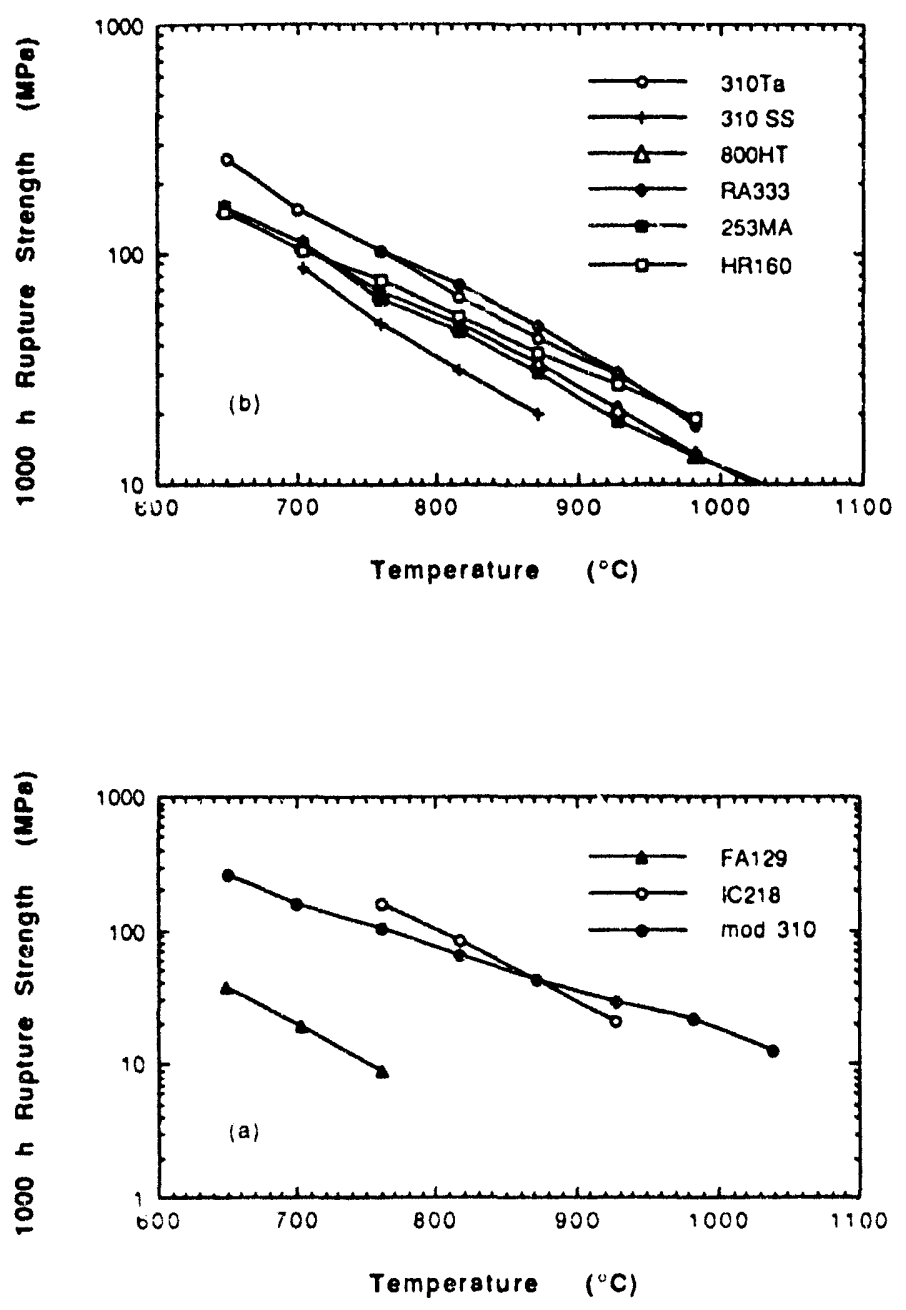

Fig. 6. Comparison of the $1000 \mathrm{~h}$ rupture strength for several alloys over the temperature range of 650 to $1100^{\circ} \mathrm{C}$. 


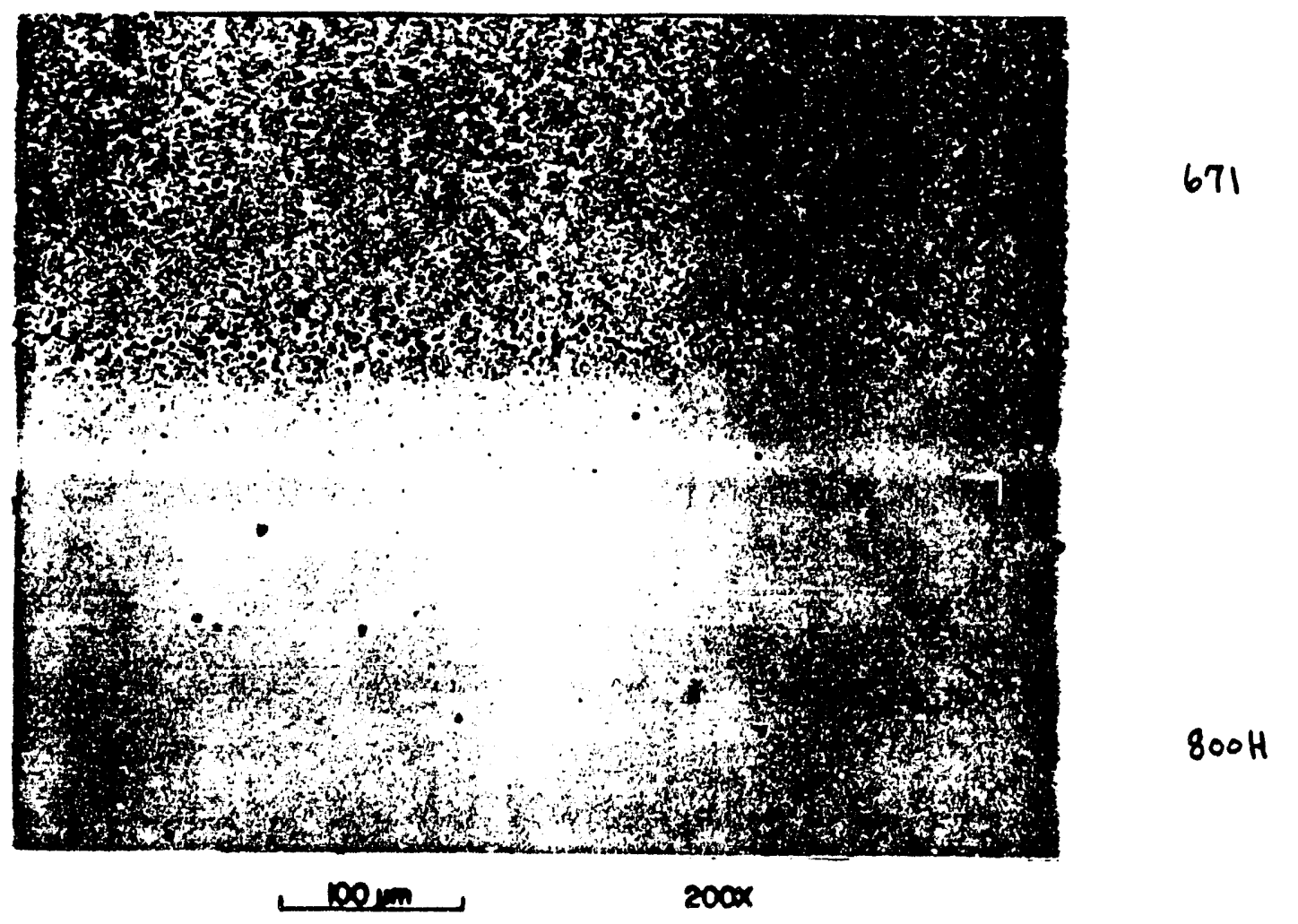

Fig. 7. Microstructure of the interface between alloy 671 cladding and alloy $800 \mathrm{H}$ after $500 \mathrm{~h}$ at $900^{\circ} \mathrm{C}$ with one thermal cycle to near room temperature each day. 


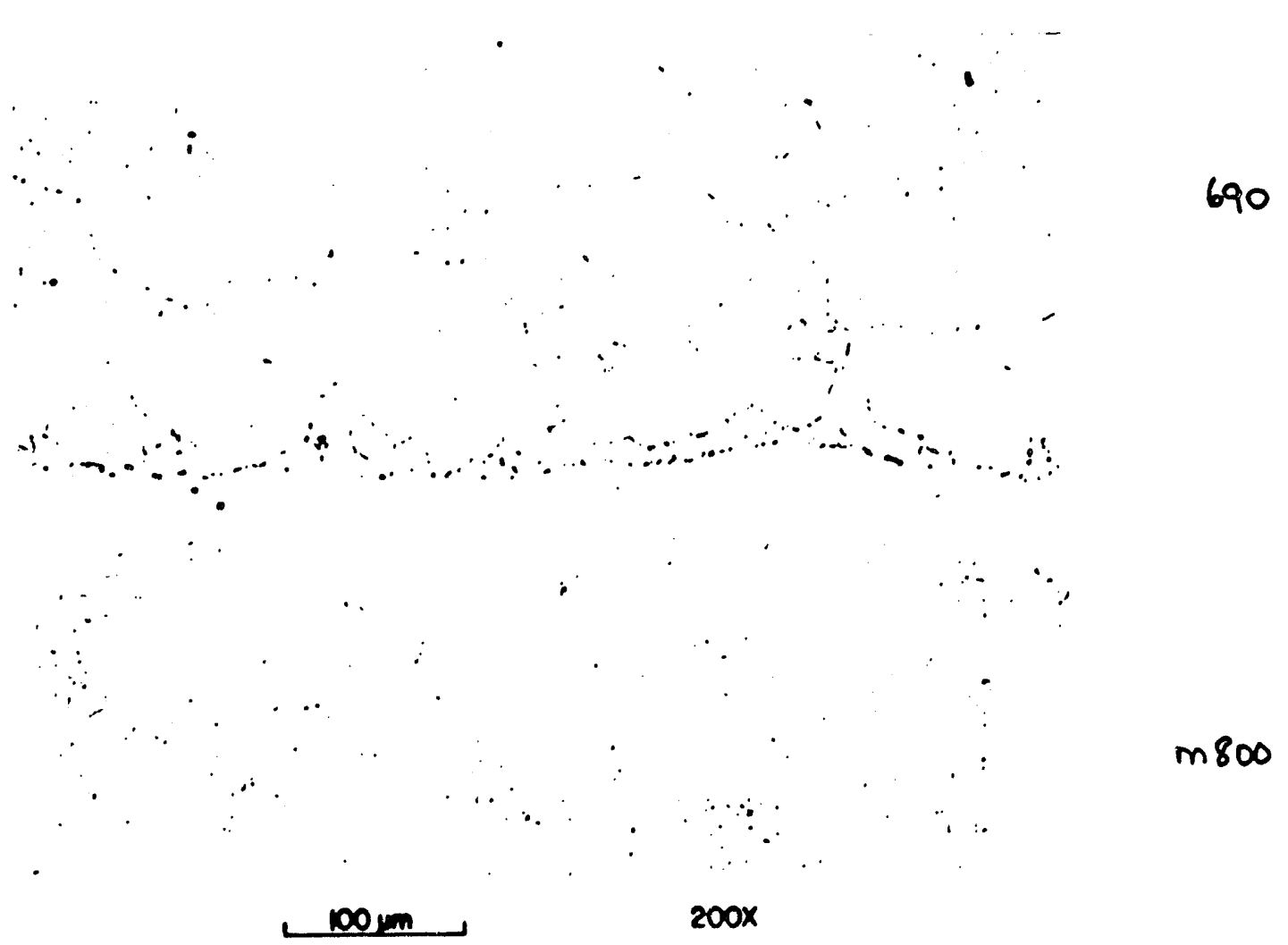

Fig. 8. Microstructure of the interface between alloy 690 cladding and modified alloy $800 \mathrm{H}$ after $500 \mathrm{~h}$ at $900^{\circ} \mathrm{C}$ with one thermal cycle to near room temperature each day. 


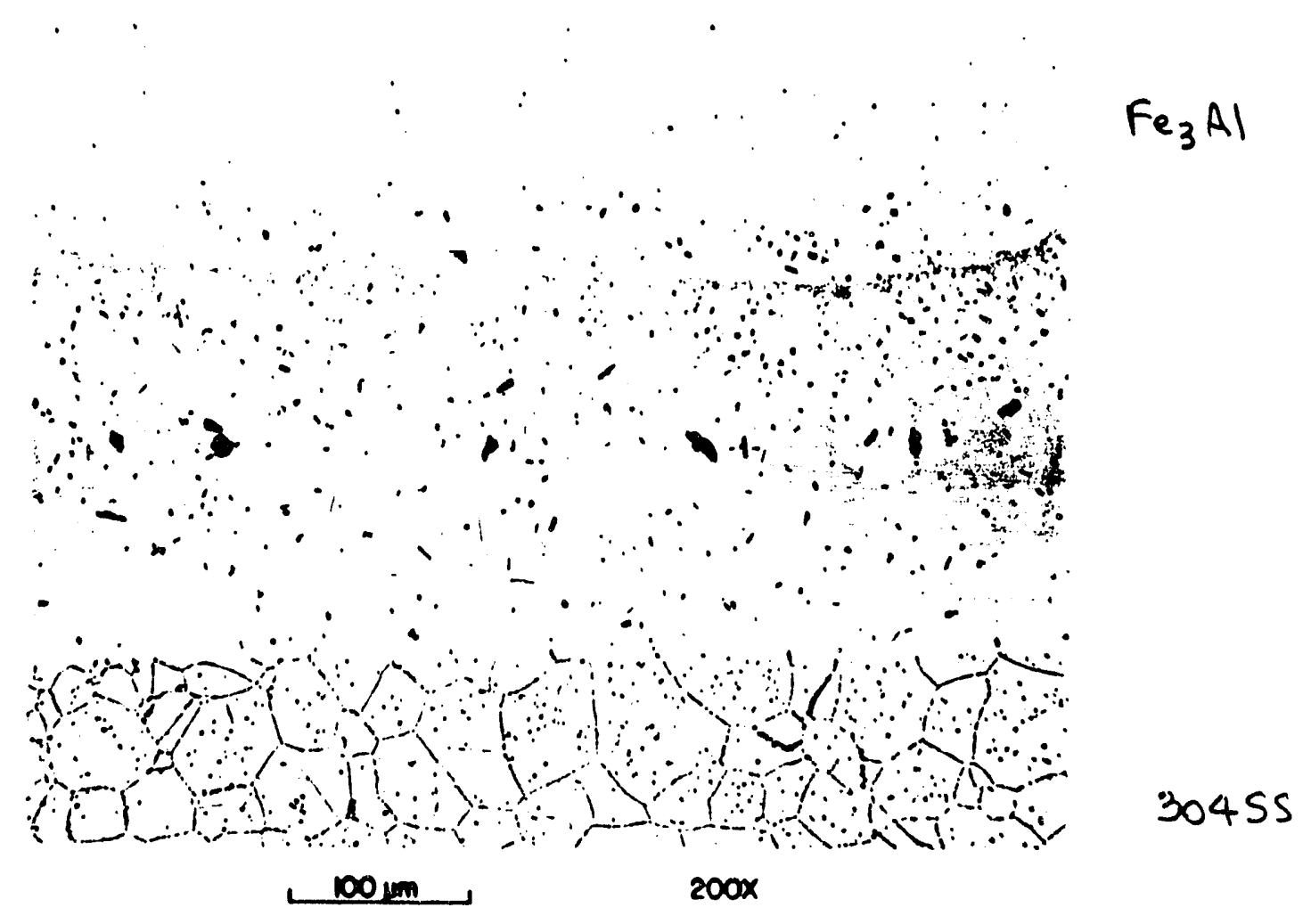

Fig. 9. Microstructure of the interface between iron aluminide cladding and 304 stainless steel after $500 \mathrm{~h}$ at $900^{\circ} \mathrm{C}$ with one thermal cycle to near room temperature each day 

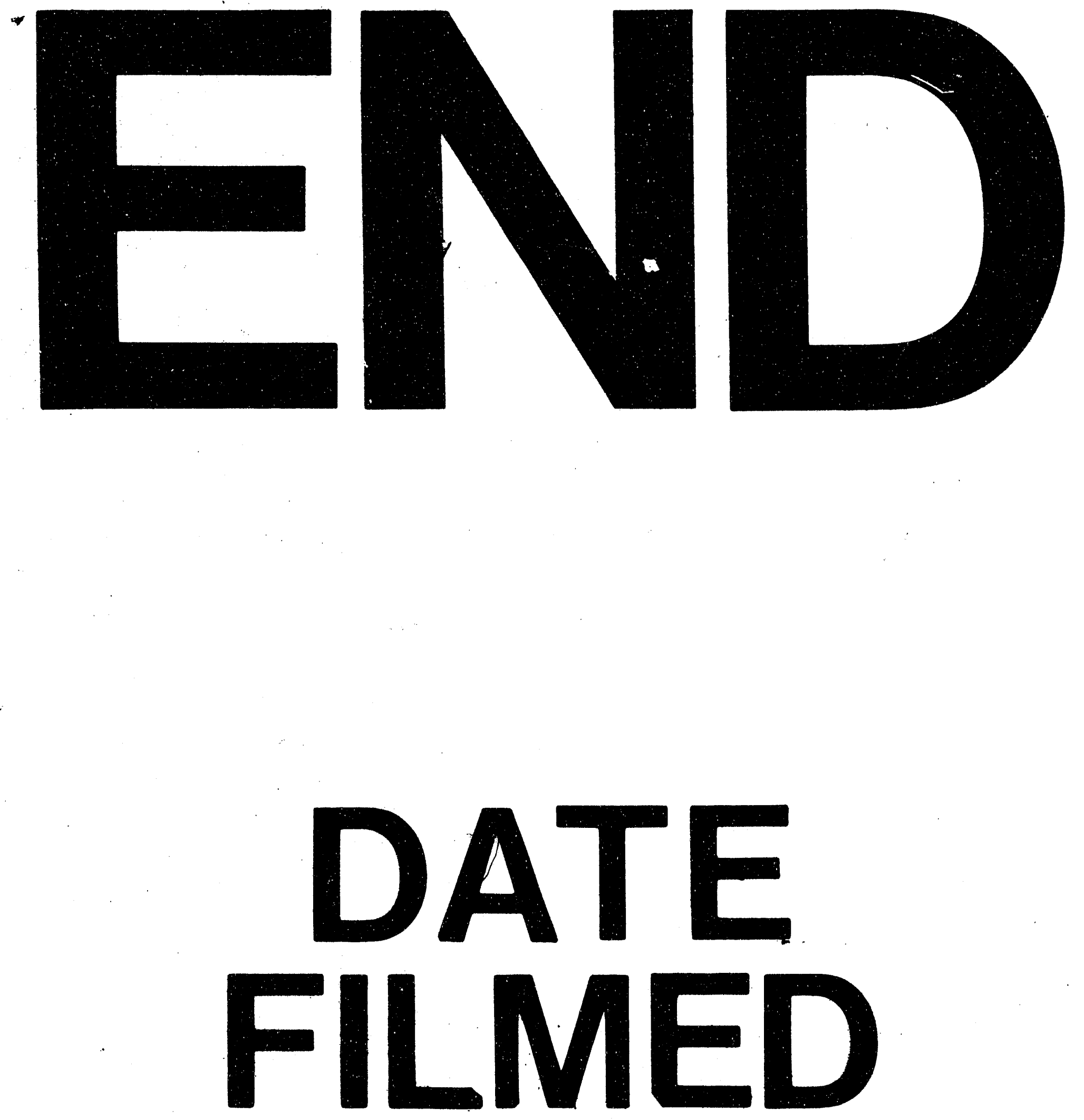

1

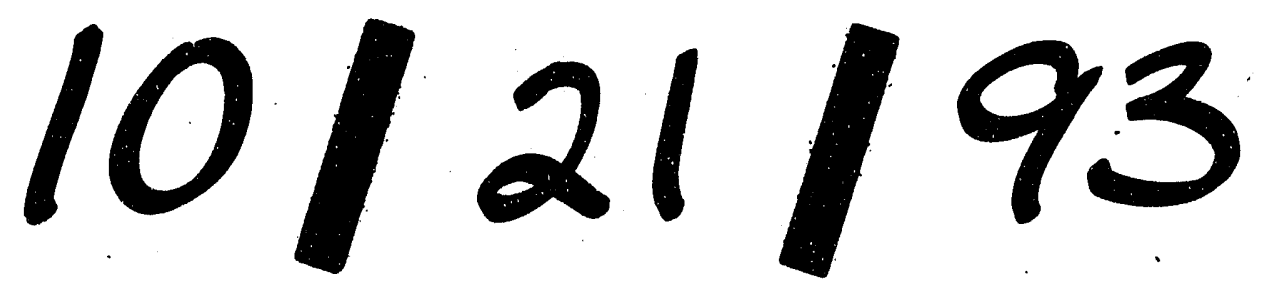


